\title{
SISTEM PAKAR DIAGNOSA PENYAKIT IBU HAMIL DENGAN METODE BACKWARD CHAINING DAN METODE CERTAINTY FACTOR
}

\author{
Najad Ibrahim, Joseph Deddy Irawan, Karina Auliasari \\ Program Studi Teknik Informatika S1, Fakultas Teknologi Industri \\ Institut Teknologi Nasional Malang, Jalan Raya Karanglo km 2 Malang, Indonesia \\ Najad16081998@gmail.com
}

\begin{abstract}
ABSTRAK
Sistem pakar adalah program komputer yang dapat meniru kemampuan pakar sesuai bidang keahlian masing-masing. Sistem pakar dibuat untuk menyerupai kemampuan pengetahuan manusia dalam menyelesaikan masalah tertentu. Sistem ini terdiri dari berberapa metode yaitu Metode Backward Chaininng (runut balik) untuk memulai penalarannya dimulai dari kesimpulan kemudian mencari sekempulan hipotesis menuju fakta yang mendung hipotesisi tersebut,kemudia akan diproses oleh metode Certainty Factor untuk menentukan persentase dari hasil backward chaining. Hasil yang diperoleh pada pengujian fungsional adalah sistem dapat berjalan dengan baik pada beberapa browser. Hasil yang diperoleh dengan melakukan beberapa uji coba sehingga mendapat keakurasian $70 \%$ sampai $80 \%$ dari hasil sistem tersebut.
\end{abstract}

Kata Kunci: Metode Backward Chaining, Metode Certainty Factor

\section{PENDAHULUAN}

Sistem pakar adalah program komputer yang dapat meniru kemampuan pakar sesuai bidang keahlian masing-masing. Sistem pakar dibuat untuk menyerupai kemampuan pengetahuan manusia dalam menyelesaikan masalah tertentu. Implementasi dari sistem pakar dapat diterapkan di semua bidang, termasuk dalam bidang kesehatan salah satunya diagnosa penyakit pada ibu hamil.

Setiap wanita menginginkan kehamilan yang berjalan dengan normal. Oleh karena itu setiap wanita harus mengetahui informasi yang benar tentang kehamilan berisiko agar mengetahui macammacamnya dan cara mengatasinya. Kehamilan yang terjadi pada setiap wanita selalu memiliki berbagai tingkat risiko dari yang ringan sampai yang berat. Kehamilan yang normal, risiko yang berat tidak dialami oleh ibu hamil. Sedangkan kehamilan yang tidak normal, terdapat risiko yang besar. Oleh karena itu, perlu adanya pengembangan sistem yang dapat membantu dalam menentukan diagnosa penyakit, yaitu berdasarkan daftar penyakit berdasarkan gejala yang dialami dengan metode backward chaining (runtut balik) yaitu memulai penalarannya dari suatu hipotesa terlebih dahulu dan untuk menguji kebenaran hipotesis tersebut harus dicari fakta-fakta yang ada dalam basis pengetahuan. Sistem pakar diagnosa penyakit pada ibu hamil dibuat berbasis web untuk memudahkan admin atau pengguna dalam mengakses sistem dimana saja.

\section{TINJAUAN PUSTAKA}

\subsection{Penelitian Terdahulu}

Desy Permata Sari (2019) pada penelitian dengan judul "Analisis Mesin Inferensi Fordward dan Backward Chaining Untuk Diagnosis Penyakit Autoimun Berbasis Web". Tujuan penelitian ini yaitu mendeteksi dalam penentuan macam dan jenis penyakit autoimun yang di alami seseorang untuk memperoleh hasil yang sesuai dengan aturan dan mampu berjalan dengan baik. Dari hasil uji keakuratan antara metode Forward Chaining dan Backward Chaining mempunyai keakuratan yang sama. [1].

Karunia Malik (2017) pada penelitian dengan judul "Sistem Pakar Mendeteksi Kerusakan Gitar Menggunakan Metode Backward Chaining Berbasis Web". Tujuan penelitian ini yaitu menganalisis penyebab dari permasalahan yang terjadi pada alat musik gitar yang dimainkan. Kehadiran sistem deteksi kerusakan pada gitar diharapkan dapat membantu dalam memperbaiki alat musik gitar tanpa perlu menggunakan jasa service. [2]

Dimas Olga Nusantara dan Sumbogo Wisnu Pamungkas (2017) pada penelitian dengan judul "Sistem Pakar Analisa Penyakit Pada Tanaman Cabai Merah Mengunakan Metode Backward Chaining". Tujuan penelitian ini yaitu dapat memudahkan petani khususnya yang tidak paham dengan bagaimana cara mendiagnosa dan penanganan penyakit pada tanaman cabai merah saat budidaya tanaman cabai. [3]

Bella Anita Agustin Maulina dan Harrison D.S (2016) pada penelitian dengan judul "Sistem Pakar Diagnosis Hama Dan Penyakit Tanaman Kacang Tanah Berbasis Desktop Dengan Metode Backward Chaining". Tujuan penelitian ini yaitu Dapat memberikan kemudahan dalam mendapatkan informasi yang akurat mengenai gejala, penyakit dan pengendalian pada tanaman kacang tanah dan memudahkan bagi petani dalam melakukan penanggulangan terhadap hama dan penyakit pada tanaman kacang tanah. [4]

Achmad Nur dan Dedy Ikhsan (2017) penelitian dengan judul "Perancangan Sistem Pakar Menggunakan Metode Backward Chaining Untuk Diagnosa Penyakit Pada Hewan Ternak Sapi Berbasis 
Web". Tujuan penelitian ini yaitu untuk membantu para peternak sapi dalam upaya identifikasi awal penyakit untuk mengambil keputusan secara mandiri dan nantinya akan menghasilkan kesimpulan awal (diagnosa) yang dapat dijadikan pedoman bagi peternak sapi dalam mengenali penyakit yang ada. [5]

Yenita Wijayana (2019) penelitian dengan judul "Sistem pakar kerusakan hardware komputer dengan metode backward chaining berbasis web". Tujuan penelitian ini yaitu dapat membantu para teknisi untuk mendiagnosa kerusakan pada perangkat keras (hardware) komputer dengan lebih praktis dan cepat sehingga dapat menghemat waktu. [6]

Priskilla Puji Larasati (2019) penelitian dengan judul "Sistem pakar diagnosa penyakit skizofrenia menggunakan metode certainty factor berbasis web" Tujuan penelitian ini yaitu membantu memudahkan masyarakat untuk melakukan diagnosa penyakit skizofrenia dan mengetahui jenis jenis penyakit skizofrenia dengan masing-masing gejalanya [7]

Ayu Puji Astuti (2017) penelitian dengan judul "Sistem pakar untuk mendiagnosa [enyakit ginjal dengan metode forward chaining menggunakan certainty factor" tujuan penelitian ini yaitu untuk mengimplementasikan sistem pakar untuk mendiagnosa penyakit ginjal berbasis website dan memudahkan warga Indonesia untuk mengenali ciriciripenyakit ginjal [8]

Annisa Syawaliah Desfarawati (2017) penelitian dengan judul "Pengembangan sistem pakar penyakit balita menggunakan metode chaining dan certainty factor berbasis android" Tujuan Membangun basis pengetahuan yang berisi pengetahuan tentang penanganan diagnosa yang sesuai dengan gejala yang ada pada balita [9]

\subsection{Pengertian Sistem Monitoring}

Sistem monitoring atau sistem pengawasan adalah suatu upaya yang sistematik untuk menetapkan kinerja standar pada perencanaan untuk merancang sistem umpan balik informasi, untuk membandingkan kinerja aktual dengan standar yang telah ditentukan, untuk menetapkan apakah telah terjadi suatu penyimpangan tersebut, serta untuk mengambil tindakan perbaikan yang diperlukan untuk menjamin bahwa semua sumber daya perusahaan atau organisasi telah digunakan seefektif dan seefisien mungkin guna mencapai tujuan perusahaan atau organisasi. [7]

\subsection{Sistem Pakar}

Pakar adalah orang yang mempunyai knowledge atau pengetahuan dan keahlian khusus yang dimiliki dalam menangani sebuah masalah tertentu. Sistem pakar yaitu sistem yang dirancang untuk dapat menyelesaikan suatu permasalahan yang bentuknya hampir sama atau meniru kerja dari para ahli atau dokter pakar yang biasa dalam menangani permasalahan tersebut. Tujuan perancangan sistem pakar untuk mempermudah kerja dalam menentukan suatu penyakit autoimun berdasarkan gejala-gejala yang dialami. Sistem pakar terbagi dari 2 bagian utama yaitu lingkungan pengembangan sistem pakar digunakan untuk memasukkan pengetahuan ke dalam lingkungan sistem pakar dan lingkungan konsultasi digunakan oleh pengguna yang bukan pakar guna memperoleh pengetahuan pakar. [1]

\subsection{Metode Backward Chaining}

Backward chaining adalah pendekatan yang dimotori tujuan (goal-driven). Dalam pendekatan ini pelacakan di mulai dari tujuan, selanjutnya dicari aturan yang memiliki tujuan tersebut untuk kesimpulannya. Selanjutnya proses pelacakan menggunakan premis untuk aturan tersebut sebagai tujuan baru dan mencari aturan lain dengan tujuan baru sebagai kesimpulannya. Proses berlanjut sampai semua kemungkinan di temukan (Arhami, 2005). Jadi Permasalahan utama dari backward chaining adalah mencari kaitan antara fakta-fakta yang ada terhadap hipotesa-hipotesa. Fakta yang ada disebut sebagai bukti atau kesimpulan dalam metode backward chaining yang mengindikasikan jika fakta tersebut digunakan untuk mendukung hipotesa, dengan cara yang sama bukti atau kesimpulan yang dikehendaki digunakan untuk membuktikan sebuah rule.[2]

\subsection{Metode Certainty Factor}

Certainty Factor atau faktor kepastian diperkenalkan pertama kali pada tahun 1975 oleh shortliffe buchanan. Certainty factor adalah metode untuk mendapatkan suatu kepastian dari suatu data,derajat gabungan kepercayaan dan ketidakpercayaan umumnya dinyatakan dalam satu rangka harga dari suatu data.seorang pakar seperti penangkar dapat menganalisis informasi yang ada untuk memberikan kepastian dari suatu data. Sebagai implementasinya adalah memanfaatkan dari suatu peralatan seperti computer, notebook dan lainnya [3]

\subsection{WEB}

Situs web (bahasa Inggris: website) adalah suatu halaman web yang saling berhubungan yang umumnya berada pada peladen yang sama berisikan kumpulan informasi yang disediakan secara perorangan, kelompok, atau organisasi. Sebuah situs web biasanya ditempatkan setidaknya pada sebuah server web yang dapat diakses melalui jaringan seperti Internet, ataupun jaringan wilayah lokal (LAN) melalui alamat Internet yang dikenali sebagai URL. Gabungan atas semua situs yang dapat diakses publik di Internet disebut pula sebagai World Wide Web atau lebih dikenal dengan singkatan WWW. Meskipun setidaknya halaman beranda situs Internet umumnya dapat diakses publik secara bebas, pada prakteknya tidak semua situs memberikan kebebasan bagi publik untuk mengaksesnya, beberapa situs web mewajibkan pengunjung untuk melakukan pendaftaran sebagai anggota, atau bahkan meminta pembayaran untuk dapat menjadi aggota untuk dapat 
mengakses isi yang terdapat dalam situs web tersebut. [4].

\subsection{HTML}

Hypertext Markup Language (HTML) adalah sebuah bahasa markah yang digunakan untuk membuat sebuah halaman web, menampilkan berbagai informasi di dalam sebuah penjelajah web Internet dan pemformatan hiperteks sederhana yang ditulis dalam berkas format ASCII agar dapat menghasilkan tampilan wujud yang terintegerasi.

HyperText Markup Language merupakan kepanjangan dari bahasa pemograman HTML, yaitu bahasa pemrograman standar yang digunakan untuk membuat sebuah halaman web. HTML dapat diakses untuk menampilkan berbagai bentuk informasi dalam sebuah Browser atau penjelajah web Internet, seperti Google Chrome, Mozilla Firefox, Bing, Internet Explorer. Meskipun HTML digunakan untuk membuat halaman web yang bisa diakses melalui internet, namun pembuatan halaman web dapat dikerjakan secara offline.

\section{METODE PENELITIAN}

\subsection{Kebutuhan Fungsional}

Kebutuhan fungsional menggambarkan proses kegiatan yang akan diterapkan dalam sebuah sistem. Pada sistem pakar diagnosa penyakit pada ibu hamil ini memiliki kebutuhan fungsional sebagai berikut :

1. Sistem memiliki fasilitas login dengan memasukkan username dan password

2. Sistem mampu menginputkan data penyakit dan data gejala yang akan diproses

3. Sistem mampu melakukan proses Backward Chaining

4. Sistem mampu memberikan hasil dari proses Backward Chaining

5. Sistem mampu melakukan proses Certainty factor

6. istem mampu memberikan hasil dari proses Certainty Factor

\subsection{Kebutuhan Nonfungsional}

Adapun beberapa kebutuhan fungsional pada sistem pakar diagnosa penyakit pada ibu hamil ini memiliki kebutuhan non fungsional sebagai berikut adalah :

1. Perangkat Keras (Hardware)

a. Laptop

2. Perangkat Lunak (Software)

a. Visual Studio Code

b. XAMPP

c. Web Browser

\subsection{Flowchart Sistem}

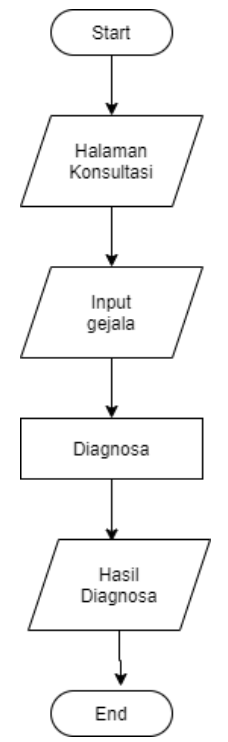

Gambar 1 Flowchart Sistem

Pada gambar 1 flowchart sistem dimulai dengan tampilan halaman konsultasi, user atau pasien diharap untuk memasukkan atau memilih beberapa macam gejala yang pasien alami. Setelah itu dilakukan proses diagnosa berdasarkan gejala yang dipilih hingga proses selesai dan keluar informasi hasil diagnosa tentang penyakit yang di derita oleh user atau pasien.

\subsection{Flowchart Admin}

Adapun alur proses cara kerja alat dijelaskan pada gambar

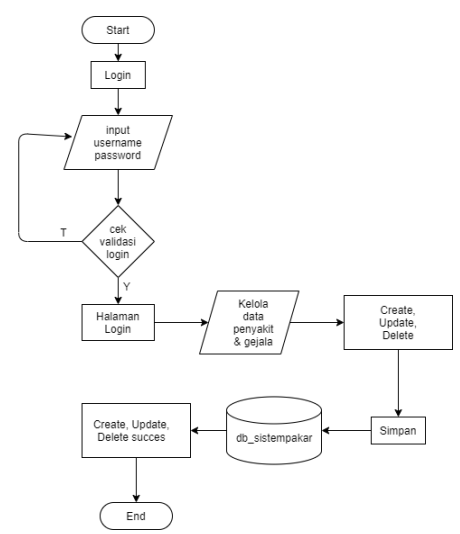

Gambar 2. Flowchart Alat

Pada gambar 2 Flowchart admin menjelaskan alur dari admin melakukan login dengan menginputkan username dan password, login akan dicek dahulu apakah username dan password yang diinputkan sudah benar. Jika benar maka admin akan masuk ke halaman menu admin, namum jika password admin salah akan kembali di halaman login. Pada halaman menu admin, admin dapat melakukan kelola data penyakit dan data gejala. 
Kemudian admin bisa melakukan create, update, delete yang akan disimpan ke database sistem pakar.

\section{IMPLEMENTASI DAN PENGUJIAN}

\subsection{Halaman Data User}

Gambar 3 menunjukkan tampilan untuk halaman mengisi data user. Admin dapat melihat, menambahkan, mengubah, menghapus data user tersebut

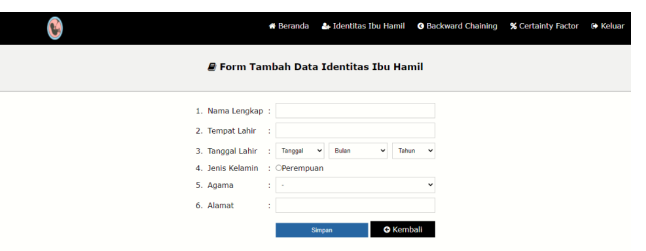

Gambar 3. Halaman Data User

\subsection{Halaman Metode Backward Chaining}

Gambar 4 menunjukkan tampilan Proses diagnosis pada halaman user menggunakan metode backward chaining.

\section{(c)}

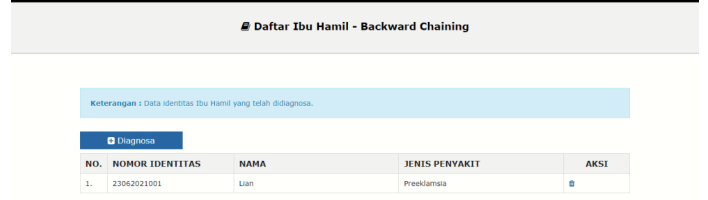

Gambar 4.Halaman Metode Backward Chaining

\subsection{Halaman Metode Certainty Factor}

Gambar 5 menunjukkan tampilan Proses diagnosis pada halaman user menggunakan metode Certainty Factor.

\section{c}

$$
\text { Q Daftar Gejala - Certainty Factor }
$$

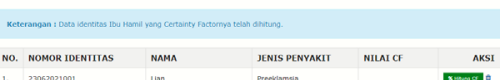

Gambar 5. Halaman Metode Certainty Factor

\subsection{Pengujian Fungsional User}

Tabel 1. Hasil pengujian Fungsional user

\begin{tabular}{|c|l|c|c|}
\hline No & Fungsi Yang Diuji & Berhasil & Gagal \\
\hline 1 & Login & $\sqrt{ }$ & - \\
\hline 2 & Halaman Beranda & $\sqrt{ }$ & - \\
\hline 3 & Halaman Identitas & $\sqrt{ }$ & - \\
\hline & a. Tambah data & $\sqrt{ }$ & - \\
\hline & b. Edit Data & $\sqrt{ }$ & - \\
\hline & c. Hapus & $\sqrt{ }$ & - \\
\hline 4 & Halaman Backward Chaining & $\sqrt{ }$ & - \\
\hline
\end{tabular}

\begin{tabular}{|c|l|c|c|}
\hline 5 & Halaman Certainty Factor & - & $\checkmark$ \\
\hline 6 & Logout & $\checkmark$ & - \\
\hline
\end{tabular}

Dari hasil pengujian fungsional User pada tabel 1 menunjukkan hasil bahwa halaman user berjalan dengan baik namun terdapat kendala dimana tampilan hasil dari halaman certainty factor tidak tampil.

\subsection{Pengujian Fungsional Admin}

Tabel 2. Hasil Pengujian Fungsional Admin

\begin{tabular}{|c|l|c|c|}
\hline No & Fungsi Yang Diuji & Berhasil & Gagal \\
\hline 1 & Login & $\sqrt{ }$ & - \\
\hline 2 & Halaman Beranda & $\sqrt{ }$ & - \\
\hline 3 & Halaman Jenis Penyakit & $\sqrt{ }$ & - \\
\hline & a. Tambah data & $\sqrt{ }$ & - \\
\hline & b. Edit Data & $\sqrt{ }$ & - \\
\hline & c. Hapus & $\sqrt{ }$ & - \\
\hline 4 & Halaman Gejala & $\sqrt{ }$ & - \\
\hline & a. Tambah data & $\sqrt{ }$ & - \\
\hline & b. Edit Data & $\sqrt{ }$ & - \\
\hline & c. Hapus & $\sqrt{\mid c}$ \\
\hline 5 & Halaman Basis Pengetahuan & \multicolumn{2}{|c|}{} \\
\hline 6 & Logout & \multicolumn{2}{|l}{} \\
\hline
\end{tabular}

Dari hasil pengujian fungsional Admin pada tabel 2 menunjukkan hasil bahwa halaman Admin berjalan dengan baik pada web browser.

\subsection{Pengujian Browser}

Pengujian aplikasi penggunaan browser ini dilakukan dengan menggunakan dua browser. Dimana pengujian ini dilakukan untuk mengetahui tingkat keberhasilan penggunaan browser. Hasil pengujian aplikasi dengan menggunakan 2 browser yang berbeda, semua tampilan dan fungsi aplikasi dapat berjalan $100 \%$ pada 2 browser yaitu Microsoft Edge versi 91.0.864.48 dan Google Chrome versi 91.0.4472.101. Berikut adalah tabel hasil pengujian dari pembuatan aplikasi menggunakan dua browser yang ditunjukkan pada Tabel 3.

Tabel 3. Hasil Pengujian Browser

\begin{tabular}{|c|l|c|c|}
\hline No & \multicolumn{1}{|c|}{ Proses User } & $\begin{array}{c}\text { Microsfot } \\
\text { Edge }\end{array}$ & Google Chrome \\
\hline 1 & Login & $\sqrt{ }$ & - \\
\hline 2 & Halaman Beranda & $\sqrt{ }$ & - \\
\hline 3 & Halaman Identitas & $\sqrt{ }$ & - \\
\hline & d. Tambah data & $\sqrt{ }$ & - \\
\hline & e. Edit Data & $\sqrt{ }$ & - \\
\hline & f. Hapus & $\sqrt{ }$ & - \\
\hline 4 & Halaman Backward Chaining & $\sqrt{ }$ & - \\
\hline 5 & Halaman Certainty Factor & $\sqrt{ }$ & - \\
\hline 6 & Logout & &
\end{tabular}




\subsection{Perhitungan Certainty Factor}

Tabel 4. menunjukan rumus Certainty Factor

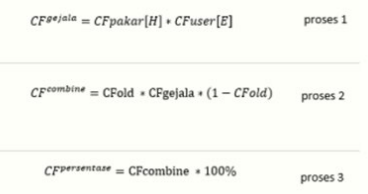

\subsection{Nilai Terminator}

Tabel 5. menunjukkan nilai terminator..

\begin{tabular}{|c|c|c|}
\hline No & Keterangan & Nilai Terminator \\
\hline 1. & Sangat yakin & 1.0 \\
\hline 2. & Yakin & 0.8 \\
\hline 3. & Cukup yakin & 0.6 \\
\hline 4. & Kurang yakin & 0.4 \\
\hline 5. & Tidak tahu & 0.2 \\
\hline 6. & Tidak & 0 \\
\hline
\end{tabular}

\subsection{Jawaban dari Pakar}

Tabel 6. menunjukkan nilai jawaban dari pakar

\begin{tabular}{|c|c|c|c|}
\hline no & kode & GEJALA & NILAI CF PAKAR \\
\hline 1 & HB1 & MUDAH LESU & 0,8 \\
\hline 2 & HB2 & LELAH & 0,4 \\
\hline 3 & HB3 & SESAK NAFAS & 0,8 \\
\hline 4 & HB4 & KUUT PUCAT & 0,2 \\
\hline 5 & HB5 & MUDAH PUSING & 0,4 \\
\hline
\end{tabular}

\subsection{Jawaban dari Pasien}

Tabel 7. menunjukkan nilai jawaban dari pasien.

\begin{tabular}{|c|c|c|}
\hline NO & Kode & Jawaba pasien \\
\hline 1 & HB1 & 0,4 \\
\hline 2 & HB2 & 0,8 \\
\hline 3 & HB3 & 0,4 \\
\hline 4 & HB4 & 0,6 \\
\hline 5 & HB5 & 0,4 \\
\hline
\end{tabular}

\subsection{Proses Perhitungan}

Tabel 8. menunjukan proses perhitungan certainty factor.

$\begin{aligned} \mathrm{CF}(\mathrm{H}, \mathrm{E}) & =\mathrm{CF}(\mathrm{H}) 1 * \mathrm{CF}(\mathrm{E}) 1 \\ & =0.8 * 0.4 \\ & =0.32 \\ \mathrm{CF}(\mathrm{H}, \mathrm{E}) & =\mathrm{CF}(\mathrm{H}) 2 * \mathrm{CF}(\mathrm{E}) 2 \\ & =0.4 * 0.8 \\ & =0.32 \\ \mathrm{CF}(\mathrm{H}, \mathrm{E}) & =\mathrm{CF}(\mathrm{H}) 3 * \mathrm{CF}(\mathrm{E}) 3 \\ & =0.8 * 0.4 \\ & =0.32 \\ \mathrm{CF}(\mathrm{H}, \mathrm{E}) & =\mathrm{CF}(\mathrm{H}) 4 * \mathrm{CF}(\mathrm{E}) 4 \\ & =0.2 * 0.6 \\ & =0.12 \\ \mathrm{CF}(\mathrm{H}, \mathrm{E}) & =\mathrm{CF}(\mathrm{H}) 5 * \mathrm{CF}(\mathrm{E}) 5 \\ & =0.4 * 0.4 \\ & =0.16\end{aligned}$

\subsection{Proses Perhitungan Combine}

Tabel 9. menunjukkan proses perhitungan combine.

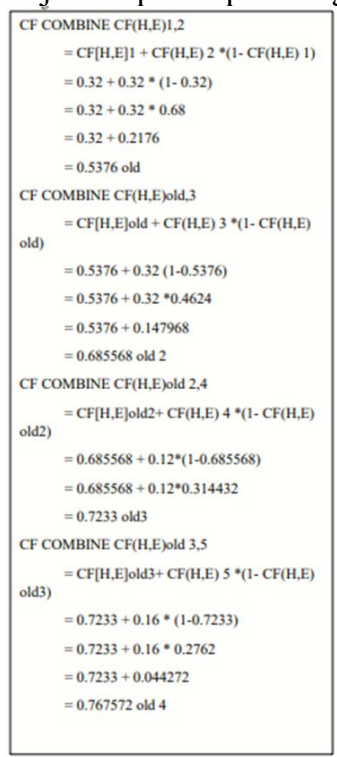

\subsection{Jawaban dari Pakar}

Tabel 9. menunjukkan proses perhitungan persentase dalam menggunakan rumus Certainty Factor.

$$
\begin{aligned}
\text { CF persentase }=\text { Cfoombine } * 100 \% \\
=0.767572 * 100 \% \\
=76.75
\end{aligned}
$$

\section{KESIMPULAN DAN SARAN}

\subsection{Kesimpulan}

Berdasarkan beberapa pengujian yang telah dilakukan didapatkan kesimpulan :

1. Hasil pengujian fungsional menunjukkan hasil 100 $\%$, artinya semua fitur web dapat berjalan pada google chrome, Microsoft Edge dan Uc Browser.

2. Hasil pengujian pembacaan sensor dht11 menunjukkan hasil 90\%, artinya sensor dht11 dapat berjalan dengan baik.

3. Hasil pengujian logika fuzzy menunjukkan hasil $80 \%$, artinya logika fuzzy dapat diterapkan dengan baik pada monitoring ternak ayam petelur.

4. Hasil pengujian browser menunjukkan hasil $100 \%$, yang artinya fitur web dapat berjalan dengan lancar pada Microsoft Edge dan Google Chrome.

\subsection{Saran}

1. Sistem Pakar Diagnosis penyakit Pada ibu hami dengan menggunakan metode backward chaining dan certainty factor dapat dikembangkan menjadi pemrograman android.

2. Sistem pakar diagnosis penyakit pada ibu hamil dengan metode backward chaining dan metode certainty factor ini dapat dikembangkan dengan menambahkan kontak langsung dengan Pakar Terkait. 


\section{DAFTAR PUSTAKA}

[1] Desy Permata Sari, (2019). Analisis Mesin Inferensi Forward Dan Backward Chaining Untuk Diagnosis Penyakit Autoimun Berbasis Web. Jati (Jurnal Mahasiswa Teknik Informatika) Volume 3, No2, September 2019.

[2] Karunia Malik (2017). Sistem Pakar Mendeteksi Kerusakan Gitar Menggunakan Metode Backward Chaining Berbasis Web. Jati(Jurnal Mahasiswa Teknik Informatika) Volume 1,No 2,September 2017.

[3] Dimas Olga Nusantara dan Sumbogo Wisnu (2017) Sistem Pakar Analisa Penyakit Pada Tanaman Cabai Merah Menggunakan Metode Backward Chaining. STMIK AMIKOM Yogyakarta,4 februari 2017.

[4] Bella Anita Agustin Maulina (2016) Sistem Pakar Diagnosis Hama Dan Penyakit Tanaman Kacang Tanah Berbasis Dekstop Dengan Metode Backward Chaining. Media jurnal informatika Volume 8, No 1,Periode juli 2016

[5] Achmad Nur dan Dedy Ikhsan (2016). Perancangan Sistem Pakar Menggunakan Metode Backwardchaining Untuk Mendiagnosa
Penyakit Pada Hewan Ternak Sapi Berbasis Web. STMIK AMIKOM Yogyakarta,4 februari 2017.

[6] Yenita Wijayana (2019). Sistem Pakar Kerusakan Hardware Komputer Dengan Metode Backward Chaining Berbasis Web. Media Elektrika, Vol.12, No.2, Desember 2019

[7] Priskilla Puji Larasati. (2019). Sistem Pakar Diagnosis Penyakit Skizofrenia Menggunakan Metode Certainy Factor Berbasis Web. JATI (Jurnal Mahasiswa Teknik Informatika) Vol. 3 No. 1, Maret 2019

[8] Ayu Puji Astuti.(2017). Sistem Pakar Untuk Mendiagnosa Penyakit Ginjal Dengan Metode Forward Chaining Menggunakan Certainty Factor. JATI (Jurnal Mahasiswa Teknik Informatika) Vol. 1 No. 1, Maret 2017

[9] Annisa Syawaliah Desfarawati (2017) Pengembangan Sistem Pakar Penyakit Pada Balita Menggunakanmetode Forward Chaining Dan Certainty Factor Berbasis Android. JATI (Jurnal Mahasiswa Teknik Informatika) Vol. 1 No. 1, Maret 2017 